\title{
The Prevalence of Diabetes Mellitus in Male Saudi Arabs
}

\author{
R. A. Bacchus, J. L. Bell, M. Madkour and B. Kilshaw \\ Department of Pathology, Riyadh Military Hospital, Riyadh, Kingdom of Saudi Arabia
}

Summary. The prevalence of diabetes mellitus in 1385 males in the Al-Kharj area of Saudi Arabia was studied using the WHO criteria for screening and interpretation of glucose tolerance tests [1]. The prevalence was found to increase with age. No diabetic patients were found in the $\leqslant 24$ year age group and only one $(0.3 \%)$ in the age range: $25-34$ years. There were seven (2.6\%) in the age range: $35-44$ years, $17(9.6 \%)$ in the age range:
45-54 years, six (11\%) in the age range: $55-64$ years and three $(23 \%)$ in the age range: $\geqslant 65$ years. The cases detected were relatively symptom free, but $65 \%$ of the diabetic patients were overweight.

Key words: Diabetes mellitus, Saudi Arabia, male, weight, serum glucose, age.
Saudi Arabia is an area of developing medical care and there is an impression, fostered both by the medical and non-medical population, that diabetes mellitus is common, although prevalence studies have not been carried out. It was the purpose of the present study to establish the prevalence of diabetes mellitus in native born Saudi Arabians in the rural Al-Kharj region of Saudi Arabia.

\section{Subjects and Methods}

One thousand three hundred and eighty five males of whom 1,068 were fasting and 317 non-fasting, were surveyed. Informed consent was obtained from all participants. The population was told in advance that the survey was to be carried out. They were not specifically told that the object of the survey was to detect diabetes but were told that a survey of the population was to be done to find out the concentrations of chemical substances present in the blood of Saudi Arabians. The volunteers were government and municipal salaried workers living in a rural area, but not employed in agricultural pursuits. The number, sex distribution and age ranges of the population living in the Al-Kharj area is not known accurately. Date and place of birth, weight and height were recorded. The age range of the subjects studied is shown in Table 1 . The largest age group surveyed was that between 15 and 24 years. Subjects with birth places throughout the country were studied with the largest number (34\%) being from the Riyadh area, which includes Al-Kharj, followed by the Abha area (16\%) and the Buraydah area (15\%). Venous blood samples were taken with the subject in the seated position, without stasis, into plain tubes and allowed to clot at room temperature ( 23 $\pm 1^{\circ} \mathrm{C}$ ) for $15-20 \mathrm{~min}$ before centrifugation. The sera were separated immediately and stored at $4^{\circ} \mathrm{C}$ until analysis the next day.

Glucose analysis was performed on the sequential multiple anaIyser with computer (Technicon Instruments, Tarrytown, New York, USA). Serum glucose assay on this instrument is by a glucose oxidase procedure based on the method of Gochman and Schmitz [2].
Glucose tolerance tests and the interpretation of results (overt diabetes and impaired glucose tolerance) were carried out according to the recommendations of the WHO Expert Committee on Diabetes Mellitus [1]. Further investigations were made on all fasting subjects with a glucose value of $\geqslant 7.0 \mathrm{mmol} / 1$ and non-fasting subjects with a glucose value of $\geqslant 8.0 \mathrm{mmol} / 1$ [1]. Glucose tolerance tests were carried out on all fasting males with a glucose level of $7.0-7.9 \mathrm{mmol} / 1$. Glucose tolerance tests were not carried out on fasting males with a glucose level of $\geqslant 8.0 \mathrm{mmol} / 1$ but diabetes was confirmed by repeat fasting glucose levels of $\geqslant 8.0 \mathrm{mmol} / 1$ at a later date. Glucose tolerance tests were also carried out on males who in the original screen had a non-fasting glucose level of 8.0 to $12.0 \mathrm{mmol} / 1$ and further fasting glucose levels and/ or glucose tolerance tests in men with non-fasting glucose levels of $\geqslant$ $12.0 \mathrm{mmol} / \mathrm{l}$

The results are the mean of duplicate analyses. Quality control of the analyses was checked using commercial quality control specimens run after every seven test samples. The within batch coefficient of variation for glucose was 0.044 at a mean value of $12.66 \mathrm{mmol} / 1$ and 0.043 at

Table 1. Age range of the Saudi Arabian population surveyed for diabetes mellitus

\begin{tabular}{lcc}
\hline $\begin{array}{l}\text { Age range } \\
\text { (years) }\end{array}$ & No. in age group & $\begin{array}{l}\text { No. as \% of } \\
\text { total males } \\
\text { surveyed }\end{array}$ \\
\hline$<15$ & 10 & 0.7 \\
$15-24$ & 528 & 38.1 \\
$25-34$ & 337 & 24.3 \\
$35-44$ & 266 & 19.2 \\
$45-54$ & 177 & 12.8 \\
$55-64$ & 54 & 3.9 \\
$\geqslant 65$ & 13 & 0.9 \\
\hline Total & 1385 & \\
\hline
\end{tabular}


Table 2. Age range of men diagnosed as having diabetes.

\begin{tabular}{lcll}
\hline $\begin{array}{l}\text { Age range } \\
\text { (years) }\end{array}$ & $\begin{array}{l}\text { No. of } \\
\text { subjects }\end{array}$ & $\begin{array}{l}\text { No. of } \\
\text { diabetic } \\
\text { patients }\end{array}$ & $\begin{array}{l}\text { No. of diabetic } \\
\text { patients as \% } \\
\text { of no. in age } \\
\text { group }\end{array}$ \\
\hline$<15$ & 10 & 0 & 0 \\
$15-24$ & 528 & 0 & 0 \\
$25-34$ & 337 & 1 & 0.3 \\
$35-44$ & 266 & 7 & 2.6 \\
$45-54$ & 177 & 17 & 9.6 \\
$55-64$ & 54 & 6 & 11 \\
$\geqslant 65$ & 13 & 3 & 23 \\
\hline
\end{tabular}

The WHO criteria for screening and interpretation of glucose tolerance tests (1) was used to diagnose diabetes. All subjects were native-born Saudi Arabians

a mean value of $7.11 \mathrm{mmol} / 1$. The between batch coefficient of variation was 0.08 at a mean level of 12.66 and 0.11 at a mean level of $7.11 \mathrm{mmol} / 1$. The mean values obtained on the controls were within the values quoted by the manufacturer.

\section{Results}

Of the 1068 men who were fasting in the original survey, $1011(94.7 \%)$ had serum glucose values $<6.0 \mathrm{mmol} / 1,24$ $(2.2 \%), 6.0-6.9 ; 13(1.2 \%), 7.0-7.9$ and $20(1.9 \%), \geqslant$ $8.0 \mathrm{mmol} / \mathrm{l}$. Glucose tolerance tests performed on the 13 men with screening glucose levels from 7.0 to $7.9 \mathrm{mmol} / 1$ showed three to have diabetes and three impaired tolerance. Seven were normal. Repeat fasting serum glucose levels at a later date on the 20 men with screening levels of $\geqslant 8.0 \mathrm{mmol} / 1$ confirmed the diagnosis of diabetes. Of 317 non-fasting males, 304 (95.9\%) had glucose levels of $<8.0 \mathrm{mmol} / 1$ and $13(4.1 \%)$, $\geqslant$ $8.0 \mathrm{mmol} / \mathrm{l}$. Two men had initial non-fasting glucose values of 8.0 to $<12 \mathrm{mmol} / 1(8.0$ and $10.3 \mathrm{mmol} / \mathrm{l})$. Glucose tolerance tests on these men were normal. Eleven had random glucose values between 12.6 and $26.2 \mathrm{mmol} / \mathrm{l}$. A repeat fasting level of $\geqslant 8.0 \mathrm{mmol} / 1$ and/or glucose tolerance tests confirmed the diagnosis of diabetes. Thus with a total population studied of 1,385 males, 34 cases of diabetes were detected $(2.5 \%)$ and three cases of impaired tolerance $(0.2 \%)$. All of the diabetic subjects detected denied having either polyuria or polydipsia. Table 2 shows the age range distribution of those diagnosed as diabetic during this survey. No diabetic patients under the age of 25 years were found and only one in the age group 25-34 years. There were seven (2.6\%; age range: $35-44$ years), 17 (9.6\%; age range: $45-54$ years), six (11\%; age range: $55-64$ years) and three ( $23 \%$; age range: $\geqslant 65$ years). In the age range up to 34 years, in which there were 875 men, only one diabetic subject was discovered $(0.1 \%)$, but in the age group of 35 years and over ( 510 men), there was an overall prevalence of $6.5 \%$. Eleven $(32.4 \%$ of the diabetic patients discovered in this survey) were of ideal body weight. The ideal body weight was taken as the mean ideal body weight $\pm 15 \%$ [3]. Nine patients $(26.5 \%)$ had weights
+15 to $+25 \%$ above their mean ideal body weight, six $(18 \%),+25$ to $+35 \%$, five $(15 \%),+35$ to $+45 \%$, and two $(6 \%),+45$ to $+55 \%$. One patient was between -15 and $-25 \%$ below his ideal body weight. In the non-diabetic males over the age of 25 years, $26 \%$ were overweight.

\section{Discussion}

Difficulty exists in comparing results of diabetes prevalence studies from different parts of the world. These difficulties are due to differences in methods of glucose assay, use of capillary or venous plasma or whole blood, differences in criteria used for establishing a diagnosis, differences in the ages of the population studied and almost complete lack of quality control data on the methods used. In spite of these draw backs, there appear to be differences in prevalence rates in different countries which cannot be completely accounted for by the above points. In the present survey, the rigid screening procedure, methods and interpretation of glucose tolerance tests as recommended by the World Health Organization Expert Committee on Diabetes Mellitus [1] were used with one exception. Thus, a value of $\geqslant 7.0 \mathrm{mmol} / 1$ was used as a screening fasting level rather than $>$ $7.0 \mathrm{mmol} / 1$ and a random value of $\geqslant 8.0$ rather than $>$ $8.0 \mathrm{mmol} / 1$. In practice the same prevalence rate would have been found in this study if either of the screening levels had been used. It may be that further cases of diabetes and more probably further cases of impaired glucose tolerance would have been found if a fasting screening value of $>6.0 \mathrm{mmol} / 1$ had been used rather than the $\geqslant 7.0 \mathrm{mmol} / \mathrm{l}$ used or the $>7.0 \mathrm{mmol} / 1$ recommended. Although the population studied was not told that the object of the survey was to detect diabetes, it is still possible that known diabetic patients might not have attended making the prevalence detected less than that which is present. On the other hand, it is known that many Saudi Arabians do not consider a raised blood glucose to be of consequence and it is possible that some of the diabetic patients found as a result of this survey knew before the survey that their blood glucose levels might be raised. There are no complete, up-to-date, population figures with demographic data available for Saudi Arabia or even for the area surveyed and therefore the true representativeness of the population studied cannot be determined. Considering all these points, the prevalence of $2.5 \%$ in men is a high prevalence when compared with studies such as that made on an Indian rural population [4]. The latter study showed a prevalence of $1.29 \%$ overall, with $1.32 \%$ in males. In that study a non-specific glucose method was used, whole blood rather than serum and much less rigid criteria for interpretation of the glucose tolerance results. All of the subjects were $>16$ years and thus comparable to this survey where the majority were $\geqslant 15$ years. The prevalence in the present study is, however, lower than that in the Pima Indians [5] where $50 \%$ of the males $\geqslant 35$ years were found to be diabetic 
compared with $6.5 \%$ in this survey. It is commonly accepted that most cases of diabetes occur after the age of 40 years [4-6] but the presence of only one male in the age group $<35$ years is striking. This may be an underestimate in that some young people may have died from the disease before a diagnosis was made. Approximately $65 \%$ of those diagnosed as diabetic were overweight compared with $26 \%$ of the non-diabetic population and diabetes in Saudi Arabia appears to be related to obesity.

A notable feature of the volunteers diagnosed as diabetic in this survey was the denial of the symptoms, polyuria and polydipsia, in spite of the fact that glucose levels as high as $26.2 \mathrm{mmol} / 1$ were found. This could mean that diabetes could go undetected for a considerable time in the Saudi Arabian population. This, together with the feeling of many of the population that a raised blood glucose is not of importance, could mean that high blood glucose might go untreated for a considerable time, perhaps until complications set in. Education of the population on the problems and treatment of diabetes should be an important aspect of health care delivery in Saudi Arabia. Further studies are in progress concerning the type of diabetes prevalent in this country.

Acknowledgements. Our thanks are due to Colonel A. H. Al-Faraidi for encouraging the survey, to General Abu Sulaiman for his help with the volunteers and to Major Bassam for continued liaison and help with arrangements. Our thanks are also due to the staff of the Clinical Chemis- try Laboratory of this hospital for expert technical assistance and to the staff of the computer department of Riyadh Military Hospital for computer analyses and to Mr. J. Patres for typing the manuscript.

\section{References}

1. World Health Organization Expert Committee on Diabetes Mellitus: second report (1980) WHO Tech Rep Ser 646: 8-12

2. Gochman N, Schmitz JM (1972) Application of a new peroxide indicator reaction to the specific automated determination of glucose with glucose oxidase. Clin Chem 18:943-950

3. Klmit CR, Knatterud GL, Meinert CL, Prout TE (1970) A study of the effects of hypoglycemic agents on vascular complications in patients with adult-onset diabetes. 1. Design, methods and baseline results. Diabetes 19: 747-783

4. Gupta OP, Joshi MH, Dave SK (1978) Prevalence of diabetes in India. Adv Metab Disord 9: 147-165

5. Bennet PH, Rushforth NB, Miller M, Lecompte PM (1976) Epidemiologic studies of diabetes in the Pima Indians. Recent Prog Horm Res 32: 333-376

6. Imperato PJ, Handelsman MB, Fofana B, Sow O (1976) The prevalence of diabetes mellitus in three population groups in the Republic of Mali. Trans R Soc Trop Med Hyg 70: 155-158

Received: 21 September 1981

and in revised form: 6 May 1982

Dr. R.A. Bacchus, Brig. Gen.

Department of Pathology

Armed Forces Hospital

P. O. Box 7897, Riyadh

Kingdom of Saudi Arabia 